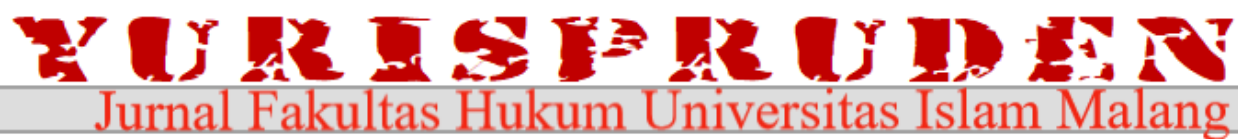

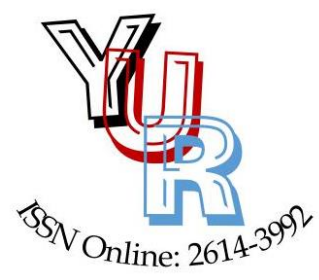

Volume 5, Number 1, Januari 2022.

Editorial Office : Faculty of Law, Univeritas Islam Malang.

Jl. Mayjen Haryono No.193, Dinoyo, Kec. Lowokwaru, Malang, Provinsi Jawa Timur, 65144.

Phone : (0341) 551932 / 551822 / (0341) 552249

E-mail : yurispruden@unisma.ac.id

Website $\quad$ : http://riset.unisma.ac.id/index.php/yur/index

\section{Presidential Threshold in Indonesian Election: An Islamic Law Perspective}

\section{Fitria Esfandiari, Sholahuddin Al-Fatih}

Faculty of Law, University of Muhammadiyah Malang, Indonesia

Jl. Raya Tlogomos No. 246, Malang, 65144, Indonesia

(0341) 464318-19, Psw: 124, 125, 188 Fax: (0341) 460782

Email : sholahuddin.alfath@gmail.com

\section{Article}

Article History

Received: Dec 15, 2021;

Reviewed: Dec 15, 2021;

Accepted: Dec 23, 2021;

Published: Jan 20, 2022;

DOI:

10.33474/yur.v5i1.14145
Abstrak

Pemilihan presiden secara langsung setiap lima tahun sekali adalah perwujudan demokrasi di Indonesia. Persoalan ambang sebagai syarat mengajukan calon presiden dan wakil presiden selalu belum menemukan solusi. Perubahan ambang batas yang awalnya 10\% kemudian angkanya berubah menjadi $20 \%$ hingga saat ini. Penelitian ini bertujuan diantaranya melakukan evaluasi terhadap disharmonisasi dalam proses penentuan ambang batas tersebut. Metode pendekatan yang digunakan adalah yuridis normatif, melalui studi kepustakaan yang dengan menggunakan bahan hukum primer dan sekunder. Hasil penelitian ini menyimpulkan bahwa rekonstruksi ambang batas pilpres berdasarkan perspektif hukum Islam sangat dibutuhkan karena sangat rentan terjadinya friksi dan tarik menarik kepentingan di kalangan partai politik.

Kata Kunci: Presiden, Ambang Batas, Pemilu, Hukum Islam.

\begin{abstract}
Direct presidential election every five years is the embodiment of democracy in Indonesia. The issue of thresholds as a condition for nominating candidates for president and vice president has always not found a solution. Changes in the threshold which was initially $10 \%$ then the number changed to $20 \%$ until now. This study aims, among others, to evaluate disharmony in the process of determining the threshold. The approach method used is normative juridical, through literature study using primary and secondary legal materials. The results of this study conclude that the reconstruction of the presidential election threshold based on the perspective of Islamic law is very much needed because it is very vulnerable to friction and tug-of-war between political parties.
\end{abstract}

Keywords: Presidential, Threshold, Election, Islamic Law. 


\section{INTRODUCTION}

Electoral law is the regulation that changes most often. ${ }^{1}$ This has implications for the material of the electoral law which also changes in the run-up to the election. ${ }^{2}$ This is directly related to political parties. Political parties $^{3}$ in democratic countries have a strategic role as a liaison in the governance process.

This is one of the factors, why electoral laws are easy to change. In simple phrase, it can be said that our country has not yet found the right electoral system and format for democratic political development. ${ }^{4}$

Political parties, for example, play a role in accordance with Article $22 \mathrm{E}$ paragraph (3) of the 1945 Constitution of the Republic of Indonesia as a constitutional forum to accommodate aspirations. ${ }^{5}$

During the election in Indonesia, participants in the election for members of the representative council stated that a political party or coalition of political parties participating in the election proposed a pair of candidates for President and Vice President. ${ }^{6}$

Since direct presidential elections have been held, the issue of the threshold requirements for nominating president and vice president candidates always comes up every time it is held. The presidential nomination threshold was $10 \%$, then increased to $20 \%$ and continues to this day. ${ }^{7}$

The imposition of a threshold in presidential nominations is useful in creating a stronger presidential system and will make it easier for elected candidates to carry out their work programs in the future. ${ }^{8}$

The requirements for the election of the nomination of President and Vice President in Indonesia as regulated in Article 6 of the 1945 Constitution of the Republic of Indonesia are further regulated in Law nomer 42 of 2008 , which is a provision for holding presidential

\footnotetext{
${ }^{1}$ Prasetio, et.al., (Desember, 2020), Problems of Democratic and Dignified Election in Indonesian Simultaneously Electoral Era, International Journal of Criminology and Sociology, Volume 9, Number (__ ), hlm. 17.

${ }^{2}$ Sholahuddin Al-fatih, (Oktober 2020), Electoral Regulation in Indonesia: Is It Modern Law ?, Unnes Law Journal, Volume 6, Number 2, hlm. 207.

${ }^{3}$ NH Siahaan, (November, 2016), Formula Penyederhanaan Jumlah Partai Politik Di Parlemen Pada Pemilihan Umum Indonesia, Politika: Jurnal Ilmu Politik, Volume 7, Number 1, hlm. 22.

${ }^{4}$ Dewi Cahyandari, Ahmad Siboy, and Sudarsono Sudarsono, (April, 2020), Urgensi Pemisahan Kewenangan Mengadili Perselisihan Hasil Pemilihan Umum Serentak, Arena Hukum, Volume 13, Number 1, hlm. (__).

5 Achmad Zakaria, (2016), Pembatasan Partai Politik Peserta Pemilihan Umum Dalam Perspektif Demokrasiarya, Jurnal Idea Hukum, Volume 2, Number 1, hlm. 54.

${ }^{6}$ Abdul Ghoffar, (September, 2018), Problematika Presidential Threshold: Decision Mahkamah Konstitusi Dan Pengalaman Di Negara Lain, Jurnal Konstitusi, Volume 15, Number 3, hlm. 18.

${ }^{7}$ Vanu Fendabi, (2019), Penerapan Ambang Batas Presidensil (Presidential Threshold) Sebagai Kebijakan Hukum Terbuka Dalam Pemilihan Umum Di Indonesia (Analisis Decision Mahkamah Konstitusi Number.53/Puuxv/2017), Skripsi, Jakarta: Ilmu Hukum UIN Syarif Hidayatullah Jakarta, hlm. 76.

8 Andi Saputra, (5 Oktober 2020), MK Bawa Nasib Gugatan Rizal Ramli Soal Presidential Threshold Ke RPH, diakses pada 23 Desember 2021, detikNews:
} 
elections in Indonesia, still has fundamental problems. $^{9}$

Among them are the provisions governing the requirements for the nomination of President and Vice President in Article 9 of Law no. 42 of 2008 regarding the provisions on the presidential candidate threshold or termed the Presidential Threshold (PT). ${ }^{10}$ The minimum requirement for support for the presidential nomination or presidential threshold in Indonesia is still being debated, especially regarding the constitutionality of these requirements.

The Constitutional Court has twice decided on the constitutionality of the presidential nomination threshold. In decision Number 51-52-59/PUU-VI/2008, the Constitutional Court stated that setting the threshold is an open legal policy, which was later reaffirmed in Decision Number 53/PUU$\mathrm{XV} / 2017$.

In countries with presidential systems, such as America, Brazil, Peru, Mexico, Colombia, and Kyrgyzstan, the threshold is unknown. ${ }^{11}$ They implement an open system of candidacy without the requirement of support. However, their system of government is also relatively stable, as exemplified by the United States. ${ }^{12}$

If the Presidential Threshold is one way to strengthen the Presidential system through simplification of political parties with the aim of creating a stable government and not causing the running government to experience difficulties in making policies with the legislature.

On the other hand, the Presidential Threshold was previously regulated in Article 9 of the Presidential Election Law, which is wrong and contrary to Article 6 A of the 1945 Constitution. ${ }^{13}$ Where the Presidential Threshold of $20 \%$ in the Presidential Election Law limits the political rights of citizens to nominate themselves as candidates. President and narrow the space for the people to get quality leaders.

Previous research on the presidential threshold has been carried out by several researchers, such as:

1) Sholahuddin Al-Fatih: ${ }^{14}$

9 Z. Firma Aditya and Sholahuddin Al-Fatih, (Februari, 2017), Democracy and Human Rights As A Solution To Resolve The Humanitarian Crisis In Muslim Countries, in Conference On Islamic Studies (ICIS), Yogyakarta.

10 Fuad Putra Perdana Ginting and Anwar Saragih, (Juli, 2018), Ilusi Demokrasi Substansial Di Indonesia: Sebuah Kritik Terhadap Implementasi Parliamentary Treshlod, Politeia: Jurnal Ilmu Politik, Volume 10, Number 2 , hlm. 85.

11 Bagus Anwar Hidayatulloh, (Oktober, 2014), Politik Hukum Sistem Pemilu Legislatif Dan Presiden Tahun 2009 Dan 2014 Dalam Decision Mahkamah Konstitusi, Jurnal Hukum Ius Quia Iustum, Volume 4, Number 21, hlm. 42 .

12 Zennis Helen, (Oktober, 2020), Problematika Pembentukan Regulasi Pemilu Dalam Mewujudkan Pemilu Serentak Yang Demokratis, Ensiklopedia Sosial Review, Volume 2, Number 3, hlm. 12.

13 Ibid

14 Sholahuddin Al-Fatih, (2016), Eksistensi Threshold Dalam Pemilu Serentak, Thesis, Surabaya: Magister Hukum Pemerintahan, hlm. 51. 
2) Lutfil Ansori ${ }^{15}$

3) Fendabi ${ }^{16}$

4) Abdul Ghoffar ${ }^{17}$ and several other researchers.

However, no one has specifically discussed the reconceptualization of the definition and function of the Presidential Threshold itself and perspective from Islamic law. Thus, it will become a novelty that provides novelty for the treasures of legal scholarship, especially electoral law, if studied and research is carried out on this matter.

Moreover, when viewed from the perspective of Islamic law, especially in the context of elections, voting and being elected is a right for every citizen. Especially, when viewed from the maqashid sharia or al ahkam al khomsah. ${ }^{18}$ Therefore, this article will study the application of the presidential threshold in the perspective of Islamic law.

This research is very important and contains a strong novelty to measure how the perspective of Islamic law sees an electoral law norm in Indonesia. Because, Indonesia is a country with a majority Muslim population, where Islamic law grows, develops and is widely adopted into positive law. ${ }^{19}$

This research was written by a juridicalnormative legal analysis research method. ${ }^{20}$ Legal research is based on the legal concept used. According to Wignyosoebroto, there is a normative concept, in which in this concept, the law is the norm, and that is identified as justice that must be manifested (ius constituendum) ${ }^{21}$

Norms manifested as explicit and formulated order positively and clearly (ius constitutum) to ensure certainty. This research in detail takes some primary and secondary legal materials. As the primary legal material, among others, in the form of legislation, such as Electoral Law and Constitutional Court Decision.

As secondary legal material in the form of national journals and international journals taken from related websites as supporting news. The journals taken are mostly in 20202021. The data that has been obtained is analyzed in the content of the analysis that

15 Lutfil Ansori, (Juni, 2017), Telaah Terhadap Presidential Threshold Dalam Pemilu Serentak 2019, Jurnal Yuridis, Volume 4, Number 1, hlm. 12.

16 Vanu Fendabi, Lo.cit.

17 Abdul Ghoffar, Lo.cit.

18 Ghofar Shidiq, (Agustus, 2009), Teori Maqashid Al-Syari'ah Dalam Hukum Islam, Majalah Ilmiah Sultan Agung, Volume 44, Number 118, hlm. 22.

19 Ali Sodiqin, (Desember, 2012), Positifikasi Hukum Islam Di Indonesia: Prospek Dan Problematikanya, Supremasi Hukum, Volume 1, Number 2, hlm. 14.

20 Irwansyah, (2020), Penelitian Hukum: Pilihan Metode \& Praktik Penulisan Artikel, ed. Ahsan Yunus, Yogyakarta: Mirra Buana Media, hlm. 92.

21 Soetandyo Wignjosoebroto, (2002), Hukum: Paradigma, Metode Dan Dinamika Masa Lalunya, Jakarta: Huma \& Elsam, hlm. 32. 
will be presented descriptively to obtain an overview of the events/problems studied. ${ }^{22}$

\section{DISCUSSION}

\section{The Debate on Threshold in Indonesia}

Thresholds, both electoral, parliamentary and presidential thresholds, began to be used in the 2004 election regime and were also adopted in the 2009 elections. $^{23}$ General elections are a means of realizing democratic ideals which do not merely determine who will sit in parliament but must be able to present the sovereignty of the people.

However, in 2009, the provisions for the threshold for obtaining parliamentary seats began to be enforced, the provisions contained in Article 202 of Law No. 10 of 2008 concerning General Elections which states that political parties participating in the general election must meet a minimum of $2.5 \%$ of the total valid votes nationally, in order to be included in determining the acquisition of seats in the DPR (House of Representative).

The presidential system is inseparable from the Parliamentary Threshold, where the Parliamentary Threshold aims to strengthen the position of the President. The implementation of policies has specific objectives depending on the needs of each country.

If the parliamentary threshold is high, there will be fewer parties occupying the parliament and the President's position will be strong. Parliamentary thresholds are created to stabilize the relationship between the Executive and the Legislature in a democracy. The presidential system is a republican system of government in which executive power is elected through elections and is separate from legislative power. The characteristics of presidential government are: ${ }^{24}$

1. Led by a president as head of government as well as head of state.

2. The executive power of the president is appointed based on people's democracy and is elected directly by them or through the people's representative body.

3. The President has the prerogative to appoint and dismiss ministers who lead departments and non-departments.

4. Ministers are only accountable to the executive power.

5. The executive power is not accountable to the legislative power.

6. Executive power cannot be overthrown by the legislature.

22 Peter Mahmud Marzuki, (2104), Penelitian Hukum, Jakarta: Kencana Prenada Media Group, hlm 43.

23 Sholahuddin Al-Fatih, (April, 2019), Akibat Hukum Regulasi Tentang Threshold DalamPemilihan Umum Legislatif Dan Pemilihan Presiden: Kajian Decision Mahkamah Konstitusi Number 52/PUU-X/2012 Dan Number 14/PUU-XI/2013, Jurnal Yudisial, Volume 12, Number 1, hlm. 16.

24 Ilham Fajar Septian, (2019), Mengefektifkan Sistem Pemerintahan Dan Menyederhanakan Sistem Partai Politik: Belajar Kepada Pemilu Jerman, Majalah Hukum Nasional, Volume 49, Number 2, hlm. 33. 
Elections can be carried out with two kinds of systems, namely a proportional representative system and a district system (single-member-constituency). ${ }^{25}$ The district system is also known as the winner's take all, because in this system the territory of the country is divided into electoral districts or electoral districts whose number is equal to the number of members of the people's representative institutions needed to be elected.

The advantage of the district system is that each candidate from a district, usually comes from the area itself or even though it comes from another area, but that person is known by the community in the area concerned. The relationship between voters and candidates for representatives has a close relationship and knows each other well. As a form of fulfilling democratic elements, elections must be held periodically, there are several factors that influence it, namely: ${ }^{26}$

1. People's opinions or aspirations regarding various aspects of national and state life tend to be dynamic. External factors in people's lives are also a consideration. Change can come from international dynamics and other external factors. This change causes the political climate to be dynamic;

2. Change character selector;

3. It needs to be done periodically to provide regeneration at the top of the power holder. It is hoped that the replacement of the leadership baton will change the condition of the country.

In the special committee (panitia khusus/pansus) of the Election Bill, the government and legislative bodies, the Electoral threshold was used in the previous election to become a parliamentary threshold. Threshold regulations for the 2009 elections are stated in Law No. 10 of 2008 and Law No. 42 of 2008 . In the 2014 election, regulations regarding threshold provisions are regulated in Law No. 8 of 2012 concerning Legislative Elections. regarding the presidential threshold is not changed and still refers to Law Number 42 of 2008 concerning Presidential Election.

With the implementation of the threshold, the public, especially political parties, have conducted several judicial reviews to the Constitutional Court ${ }^{2728}$ to test or review the validity of the application of the threshold in elections.

25 Bagian Analisis Teknis Pengawasan dan Potensi Pelanggaran, (2015), Kajian Sistem Kepartaian, Sistem Pemilu Dan Sistem Presidensiil, Sekretariat Jenderal Bawaslu RI, Jakarta: Sekretariat Jenderal Bawaslu RI, hlm. 43.

26 Agus Effendi, (Juni, 2016), Studi Komparatif Pengaturan Sistem Pemilihan Umum Anggota Dewan Perwakilan Rakyat Di Indonesia, Fiat Justisia, Volume 10, Number 2, hlm. 11.

27 Sholahuddin Al-Fatih, (September, 2017), Model Pengujian Peraturan Perundang-Undangan Satu Atap Melalui Mahkamah Konstitusi, Jurnal Ilmiah Hukum Legality, Volume 25, Number 2, hlm. 32.

28 Mardian Wibowo, (Juni, 2015), Menakar Konstitusionalitas Sebuah Kebijakan Hukum Terbuka Dalam Pengujian Undang-Undang, Jurnal Konstitusi, Volume 12, Number 2, hlm. 12. 
The reason for the reviewing is more based on the protection of human rights, especially civil and political rights of citizens which are systemically castrated by the implementation of the threshold mechanism, because many voters' votes will be wasted through this mechanism. According to the Constitutional Court, through Decision Number 3/PUU-VII/2009, it has further strengthened the existence of the threshold with a decision which states that the application of the threshold is a natural thing in elections. ${ }^{29}$

\section{Presidential Threshold on Simultaneous}

\section{Election}

Simultaneous elections are a mandate Constitutional Court Decision Number 14/PUUXI/2013. ${ }^{30}$ Through this decision, the Constitutional Court argues that the policy related to the threshold is an open legal policy or returned to the legislature. The dynamics of implementing the presidential threshold in the simultaneous elections in 2019 finally lead to the decision that the magnitude of the number presidential threshold as a requirement for political parties to be able to carry presidential and vice president candidates refers to the election results in the period previously.
In the 2019 simultaneous elections, the government through Law Number 7 of 2017 concerning General Elections, setting the numbers presidential threshold of $20 \%$ (twenty percent) of the number of seats in the House of Representatives people or get $25 \%$ (twenty five percent) of national valid votes in elections members of the House of Representatives.

Though the amount of the presidential threshold in the 2019 presidential election has not changed, but there is a stipulation that the number presidential threshold as a requirement for political parties to be able to carry presidential and vice president candidates refers to the election results in the period before, making a lot of people disappointed. Therefore, the enactment of Law Number 7 of 2017 concerning Elections General does not necessarily provide a solution, but instead it opens opportunities for conflict to arise interests in society.

At least, there has been a judicial review of the law conducted by Yusril Ihza Mahendra as representative of the Bulan Bintang Party and Rhoma Irama as representatives from the Idaman Party. ${ }^{31}$

29 Yogo Pamungkas, (April, 2014), Tinjauan Ambang Batas Perolehan Suara Berdasarkan UU No.8 Tahun 2012 Tentang Pemilihan Anggota DPR, DPD Dan DPRD Terhadap UUD 1945, RechtsVinding, Volume 3, Number 8, hlm. 12.

30 Fitria Esfandiari and Sholahuddin Al Fatih, (Desember, 2020), Initiating a Permanent Electoral Body To Resolve Dignified Election Disputes: Assessing the Effectiveness of Gakkumdu, Yustisia Jurnal Hukum, Volume 9, Number 3, hlm. 75.

31 Yusril Ihza Mahendra, (2015), Pemilu Serentak, Parliamentary Threshold \& Presidential Threshold Tak Ada Lagi, diakses pada 24 Desember 2021, Poskota, http://poskotanews.com/2015/06/30/pemilu-serentakparliamentary-treshold-dan-presidential-treshold-tak-ada-lagi/ 
In the author's opinion, it should be presidential threshold does not need to be applied to the 2019 election regime. As also conveyed by Muzakir, the application of presidential threshold in simultaneous elections considered irrelevant. ${ }^{32}$

Presidential threshold in the 2019 simultaneous elections should be not intended for presidential candidacy requirements and vice president, but rather to coalition in government. If on the 2019 election, the presidential threshold is fixed forced to enforce, then like quoting Habibullah's opinion, it should be There are two stages of elections, namely pre-election and the election itself. Pre-election aims to filter support so that the magnitude the presidential threshold applied is not in vain. ${ }^{33}$

Unfortunately, in 2019 presidential election, the government setting the numbers presidential threshold of $20 \%$ (twenty percent) of the number of seats in the House of Representatives people or get $25 \%$ (twenty five percent) of national valid votes in elections members of the House of Representatives.

From those number, only two candidates that can fulfill the requirements, those are
Jokowi-Amin (Join) and Prabowo-Sandi (Pas). In fact, there are quite several national figures who have the potential to advance in the presidential election, but are hindered by regulations regarding the presidential threshold, such as Gatot Nurmantyo, Ridwan Kamil, Agus Harimurti Yudhoyono, Muhaimin Iskandar, Zulkifli Hasan, Anies Rasyid Baswedan, Ahmad Heryawan and more.

\section{Presidential Threshold in Islamic Law Perspective}

According to Saiful Ansori, the implementation of the presidential threshold in the 2019 simultaneous elections, the level of advantages and disadvantages, is included in the dharuriyyah aspect. ${ }^{34}$ Because, both the implementation will have a positive or negative impact, but the implementation of elections must still be carried out. This is very important because it involves all aspects of the lives of Indonesian citizens, both in terms of security, protection, religion, culture, economy, law, politics and so on. ${ }^{35}$

Because if those regulation (presidential threshold) is not implemented in the presidential election, it is feared that it will emerge in the community. ${ }^{36}$ This concern is

\footnotetext{
32 Muzakir, (2016), Pileg \& Pilpres Serentak 2019, Presidential Threshold Tidak Perlu Lagi, diakses pada 22 Desember 2021, Poskota, http://poskotanews.com/.

33 Abdul Wahab Habibullah, (2015), Pemberlakuan Presidentil Threshold Dalam Pemilu Serentak, Surabaya: Airlangga, hlm. 142.

34 Saiful Ansori Ansori, (2020), Maqashid Syariah Dan Praktik Sistem Presidential Threshold Di Indonesia:, Jurisprudensi: Jurnal Ilmu Syariah, Perundang-Undangan, Dan Ekonomi Islam, Volume 12, Number 1, hlm. 14.

35 Ibid.

36 Andi Saputra, Lo.cit.
} 
not an exaggeration because if we look at the history of implementing the presidential threshold in Indonesia, there have been 13 decisions of the Constitutional Court that have decided cases related to the presidential threshold.

Table 1. Constitutional Court Decision on Presidential Threshold

\begin{tabular}{|c|c|c|}
\hline No & $\begin{array}{l}\text { Constitutional } \\
\text { Court Decision }\end{array}$ & About \\
\hline 1. & $\begin{array}{l}\text { Constitutional } \\
\text { Court Decision } \\
\text { Number 44/PUU- } \\
\text { XV/2017 }\end{array}$ & $\begin{array}{l}\text { Article } 222 \\
\text { Elction Law } \\
\text { considered as an } \\
\text { entry tool for } \\
\text { political cartels. } \\
\text { The presidential } \\
\text { threshold } \\
\text { requirement is } \\
\text { not regulated in } \\
\text { the } 1945 \\
\text { Constitution of } \\
\text { the Republic of } \\
\text { Indonesia. }\end{array}$ \\
\hline 2. & $\begin{array}{l}\text { Constitutional } \\
\text { Court Decision } \\
\text { 53/PUU-XV/2017 }\end{array}$ & $\begin{array}{l}\text { The results of } \\
\text { the } 2014 \\
\text { legislative } \\
\text { elections which } \\
\text { were used as the } \\
\text { presidential } \\
\text { threshold } \\
\text { requirement for } \\
\text { the } 2019 \\
\text { presidential } \\
\text { election mixed } \\
\text { the voter's vote. }\end{array}$ \\
\hline 3. & $\begin{array}{l}\text { Constitutional } \\
\text { Court Decision } \\
\text { 59/PUU-XV/2017 }\end{array}$ & $\begin{array}{l}\text { Article } 222 \\
\text { Election Law } \\
\text { considered to } \\
\text { hinder efforts to } \\
\text { reduce } \\
\text { transactional } \\
\text { politics. }\end{array}$ \\
\hline
\end{tabular}

\begin{tabular}{|c|c|c|}
\hline 4. & $\begin{array}{l}\text { Constitutional } \\
\text { Court Decision } \\
\text { 70/PUU-XV/2017 }\end{array}$ & $\begin{array}{l}\text { Coalition to } \\
\text { carry } \\
\text { presidential and } \\
\text { vice-presidential } \\
\text { candidates is not } \\
\text { known in the } \\
\text { presidential } \\
\text { system because } \\
\text { the President is } \\
\text { directly } \\
\text { responsible to } \\
\text { the people, not } \\
\text { to the } \\
\text { parliament/DPR }\end{array}$ \\
\hline 5. & $\begin{array}{l}\text { Constitutional } \\
\text { Court Decision } \\
\text { 71/PUU-XV/2017 }\end{array}$ & $\begin{array}{l}\text { Presidential } \\
\text { threshold } \\
\text { undermine the } \\
\text { meaning of } \\
\text { simultaneous } \\
\text { elections } \\
\text { according to } \\
\text { Constitutional } \\
\text { Court Decision } \\
\text { Number } \\
\text { 14/PUU- } \\
\text { XI/2013. }\end{array}$ \\
\hline 6. & $\begin{array}{l}\text { Constitutional } \\
\text { Court Decision } \\
\text { 72/PUU-XV/2017 }\end{array}$ & $\begin{array}{l}\text { The existence of } \\
\text { a presidential } \\
\text { threshold limits } \\
\text { the rights of } \\
\text { citizens to vote } \\
\text { for presidential } \\
\text { and vice- } \\
\text { presidential } \\
\text { candidates } \\
\text { because the } \\
\text { number of } \\
\text { presidential and } \\
\text { vice-presidential } \\
\text { pairs is limited. }\end{array}$ \\
\hline 7. & $\begin{array}{l}\text { Constitutional } \\
\text { Court Decision } \\
\text { 49/PUU- } \\
\text { XVI/2018 }\end{array}$ & $\begin{array}{l}\text { The calculation } \\
\text { of the } \\
\text { presidential } \\
\text { threshold based } \\
\text { on the results of }\end{array}$ \\
\hline
\end{tabular}

37 Article 222 Undang-Undang Number 7 Year 2017 about Election "Candidate Pairs are proposed by Political Parties or Combined Election Contesting Political Parties that meet the requirements for obtaining seats of at least 20\% (twenty percent) of the total seats in the DPR or obtaining 25\% (twenty five percent) of the nationally valid votes in the previous election for members of the DPR." 


\begin{tabular}{|c|c|c|}
\hline & & $\begin{array}{l}\text { the legislative } \\
\text { elections of the } \\
\text { previous period } \\
\text { has removed the } \\
\text { essence of the } \\
\text { implementation } \\
\text { of the election. }\end{array}$ \\
\hline 8. & $\begin{array}{l}\text { Constitutional } \\
\text { Court Decision } \\
\text { 50/PUU- } \\
\text { XVI/2018 }\end{array}$ & $\begin{array}{l}\text { The provisions } \\
\text { on the } \\
\text { presidential } \\
\text { threshold } \\
\text { discriminate } \\
\text { against the } \\
\text { rights of } \\
\text { political parties } \\
\text { participating in } \\
\text { the new } \\
\text { elections. }\end{array}$ \\
\hline 9. & $\begin{array}{l}\text { Constitutional } \\
\text { Court Decision } \\
\text { 54/PUU- } \\
\text { XVI/2018 }\end{array}$ & $\begin{array}{l}\text { The provisions } \\
\text { regarding the } \\
\text { presidential } \\
\text { threshold are } \\
\text { contrary to the } \\
\text { values of } \\
\text { Pancasila which } \\
\text { are an } \\
\text { inseparable part } \\
\text { of the opening } \\
\text { of the } 1945 \\
\text { Constitution of } \\
\text { the Republic of } \\
\text { Indonesia. }\end{array}$ \\
\hline 10. & $\begin{array}{l}\text { Constitutional } \\
\text { Court Decision } \\
\text { 58/PUU- } \\
\text { XVI/2018 }\end{array}$ & $\begin{array}{l}\text { The } \\
\text { implementation } \\
\text { of the } \\
\text { presidential } \\
\text { threshold } \\
\text { castrates and } \\
\text { limits applicants } \\
\text { from obtaining } \\
\text { alternative } \\
\text { presidential and } \\
\text { vice-presidential } \\
\text { candidates } \\
\text { because of the } \\
\text { high potential } \\
\text { for a single } \\
\text { candidate. }\end{array}$ \\
\hline 11. & $\begin{array}{l}\text { Constitutional } \\
\text { Court Decision }\end{array}$ & $\begin{array}{l}\text { The legal } \\
\text { standing of the }\end{array}$ \\
\hline
\end{tabular}

\begin{tabular}{|c|c|c|}
\hline & $\begin{array}{l}\text { 61/PUU- } \\
\text { XVI/2018 }\end{array}$ & $\begin{array}{l}\text { applicant is not } \\
\text { clear, so the } \\
\text { Constitutional } \\
\text { Court does not } \\
\text { examine the } \\
\text { subject matter of } \\
\text { the case }\end{array}$ \\
\hline 12. & $\begin{array}{l}\text { Constitutional } \\
\text { Court Decision } \\
\text { 92/PUU- } \\
\text { XVI/2018 }\end{array}$ & $\begin{array}{l}\text { The presidential } \\
\text { threshold which } \\
\text { stipulates that } \\
\text { presidential and } \\
\text { vice-presidential } \\
\text { candidates must } \\
\text { be endorsed by } \\
\text { political parties } \\
\text { and/or coalitions } \\
\text { of political } \\
\text { parties has } \\
\text { limited the right } \\
\text { of applicants to } \\
\text { run for } \\
\text { presidential } \\
\text { and/or vice- } \\
\text { presidential } \\
\text { candidates from } \\
\text { an } \\
\text { independent/ind } \\
\text { ependent path. }\end{array}$ \\
\hline 13. & $\begin{array}{l}\text { Constitutional } \\
\text { Court Decision } \\
\text { 74/PUU- } \\
\text { XVIII/2020 }\end{array}$ & $\begin{array}{l}\text { Post factum (in } \\
\text { concreto), the } \\
2019 \\
\text { Presidential } \\
\text { Election has } \\
\text { caused the loss } \\
\text { of the } \\
\text { constitutional } \\
\text { rights of PSI, } \\
\text { Perindo, the } \\
\text { Berkarya Party } \\
\text { and the Garuda } \\
\text { Party to be able } \\
\text { to nominate a } \\
\text { presidential and } \\
\text { vice-presidential } \\
\text { candidate. }\end{array}$ \\
\hline
\end{tabular}

Source: data analyzed by author

Saiful Ansori also argued that the implementation of the presidential threshold system in the 2019 simultaneous elections, the 
scope of benefits that are caused to fall into the Maqashidal-'Ammah (General Maqashid) category which is a maqashid which includes all the problems contained in universal tashri' behavior such as justice, equality, tolerance, convenience and others. ${ }^{38}$

Presidential threshold that implemented in presidential election from the perspective of Maqashid Syari'ah or Islamic law perspective, then this is an effort or means used to achieve the goals to be achieved. Although the simultaneous election system is not a perfect system for building a more democratic state administration, at least the efforts made are expected to reduce the negative impact or disadvantages result. ${ }^{39}$

Moreover, Muhamad Sofi Mubarok stated that the choice of using the presidential threshold in the presidential election is part of Ijtihad Maslahi. ${ }^{40}$ Ijtihad Maslahi (maqashidbased ijtihad) is interpreted as an effort study, analyze and find the goals behind the application of sharia texts, then apply them to the case for which the legal provisions are to be sought. ${ }^{41}$

Products produced by Ijtihad Maslahi trying to creat human benefit/advantages.
However, according to Muhamad Sofi Mubarok, Ijtihad Maslahi must be based on five principles so that the resulting policies are not authoritarian, namely: honesty, diligence, comprehensiveness, reasonableness and selfrestrain. ${ }^{4243}$

Honest mean understanding the strength and weakness from itself. ${ }^{44}$ Every judge who decides, where the decision has legal consequences, must honestly know his capacity. So, the decisions later will not cause injustice to the community. As is the case in the context of the application of the presidential threshold, in which the judges of the Constitutional Court decide that the policy is an open legal policy and is interpreted by lawmakers.

Why do constitutional judges not dare to honestly just cancel the implementation of the presidential threshold. Because, there are no clear parameters regarding the rules of the open legal policy. Moreover, the threshold policy, both parliamentary and presidential threshold always make horizontal conflict and persuade the public to submit judicial review to Constitutional Court.

38 Ansori, Lo.cit.

39 Ibid

40 Muhamad Sofi Mubarok, (Desember, 2020), Membedah Anatomi Fiqh Siyasah Dalam Decision Mahkamah Konstitusi Tentang Presidential Threshold, Tafaqquh: Jurnal Penelitian Dan Kajian Keislaman, Volume 8 , Number 2, hlm. 34.

41 Ahmad Al-Raysuni and Muhammad Jamal Barut, (2000), Al-Ijtihad: Al-Nass, Al-Waqi', AlMaslahah, Beirut: Dar al-Fikr al-Mu'asir, hlm. 77.

42 Mubarok, Lo.cit.

43 Muhammad Lutfi Hakim, (Juni, 2020), Hermeneutik-Negosiasi Dalam Studi Fatwa-Fatwa Keagamaan: Analisis Kritik Terhadap Pemikiran Khaled M. Abou El Fadl, Istinbath, Volume 19, Number 1, hlm. 42.

44 Mubarok, Lo.cit. 
However, in the Constitutional Court's decision there are two Constitutional Justices who have dissenting opinions, namely Constitutional Judge Suhartoyo and Constitutional Judge Saldi Isra (both of them give dissenting opinion that declined or denied regulation of Presidential Threshold). In the dissenting opinion it was stated that by reading the formulation of the formulation of Article 222 of the Election Law, it is difficult to argue that the message "remaining based on the provisions of the 1945 Constitution" in the Constitutional Court Decision 14/2013 was blatantly ignored by the legislators.

This means that the legislators stopped reading the considerations of the Constitutional Court in the a quo decision, only to the sentence that the requirement for the number of seats and the number of votes for political parties as a condition for nominating pairs of presidential candidates is the authority of the legislators. In fact, with the phrase "still based on the provisions of the 1945 Constitution", legislators in addition to paying attention to the provisions of Article 6A paragraph (2) of the 1945 Constitution must also pay attention to the provisions in Article 22E paragraph (1) and paragraph (2), Article 27 paragraph (1) Article 28D paragraph (1) and paragraph (3) of the 1945 Constitution which requires the guarantee of equal rights to every political party participating in the election to nominate a presidential (and vice-presidential) candidate pair.

It was further explained at that point, that the Constitutional Court should carry out its constitutional role and function in correcting or reviewing the substance of the Act, even when the amendment to the 1945 Constitution (1999-2002) appeared enthusiastic about simplifying political parties in order to support the presidential government system. In this regard, the Constitutional Court should place or give more priority to the fulfillment of the constitutional rights of the political parties participating in the election compared to the fulfillment of the assessment that the constitutional design (constitutional design or constitutional engineering) requires the simplification of the number of political parties participating in the election. So, the Constitutional Judges can implement diligence and comprehensive interpretation on their decision.

Diligence means carefully skilled in interpreting a legal norm. Comprehensiveness means the judges or lawmakers can investigate all relevant texts holistically with the topic to be solved. From these two bases, have judges and legislators/lawmakers comprehensively reviewed and understood the origins of the presidential threshold theory, how to formulate the amount and what its function is for? Have the amounts of $20 \%$ and $25 \%$ been formulated logically so that they meet the 
reasonableness principle? Are judges and legislators/lawmakers able to control themselves (self-retrain) when deciding to apply the presidential threshold?

So that the policy is not arbitrary and limits the right to be elected by people who want to run for president. So, according to the author, the best rule of dharuriyyah and Ijtihad Maslahi from Islamic law perspective or maqashid sharia related to the implementation of the presidential threshold policy is to remove the presidential threshold in presidential election. The mechanism for the requirements for presidential candidates is returned to the constitution (UUD NRI 1945).

\section{CONCLUSION}

Based on the discussion above, it can be concluded that the reconstruction of the presidential threshold in the presidential election on Islamic law perspective can be done by removing the provisions regarding the presidential threshold. This is important because the regulation regarding the presidential threshold is not in accordance with the principle of people's sovereignty and has the potential to violate the people's right to vote and be elected.

\section{REFERENCES}

\section{Journal}

Abdul Ghoffar, (September, 2018), Problematika Presidential Threshold: Decision Mahkamah Konstitusi Dan Pengalaman Di Negara Lain, Jurnal Konstitusi, Volume 15, Number 3.

Achmad Zakaria, (2016), Pembatasan Partai Politik Peserta Pemilihan Umum Dalam
Perspektif Demokrasiarya, Jurnal Idea Hukum, Volume 2, Number 1.

Agus Effendi, (Juni, 2016), Studi Komparatif Pengaturan Sistem Pemilihan Umum Anggota Dewan Perwakilan Rakyat Di Indonesia, Fiat Justisia, Volume 10, Number 2.

Ali Sodiqin, (Desember, 2012), Positifikasi Hukum Islam Di Indonesia: Prospek Dan Problematikanya, Supremasi Hukum, Volume 1, Number 2.

Bagus Anwar Hidayatulloh, (Oktober, 2014), Politik Hukum Sistem Pemilu Legislatif Dan Presiden Tahun 2009 Dan 2014 Dalam Decision Mahkamah Konstitusi, Jurnal Hukum Ius Quia Iustum, Volume 4, Number 21.

Dewi Cahyandari, Ahmad Siboy, and Sudarsono Sudarsono, (April, 2020), Urgensi Pemisahan Kewenangan Mengadili Perselisihan Hasil Pemilihan Umum Serentak, Arena Hukum, Volume 13, Number 1.

Fitria Esfandiari and Sholahuddin Al Fatih, (Desember, 2020), Initiating a Permanent Electoral Body To Resolve Dignified Election Disputes: Assessing the Effectiveness of Gakkumdu, Yustisia Jurnal Hukum, Volume 9, Number 3.

Fuad Putra Perdana Ginting and Anwar Saragih, (Juli, 2018), Ilusi Demokrasi Substansial Di Indonesia: Sebuah Kritik Terhadap Implementasi Parliamentary Treshlod, Politeia: Jurnal Ilmu Politik, Volume 10, Number 2.

Ghofar Shidiq, (Agustus, 2009), Teori Maqashid Al-Syari'ah Dalam Hukum Islam, Majalah Ilmiah Sultan Agung, Volume 44, Number 118.

Ilham Fajar Septian, (2019), Mengefektifkan Sistem Pemerintahan Dan Menyederhanakan Sistem Partai Politik: Belajar Kepada Pemilu Jerman, Majalah Hukum Nasional, Volume 49, Number 2. 
Lutfil Ansori, (Juni, 2017), Telaah Terhadap Presidential Threshold Dalam Pemilu Serentak 2019, Jurnal Yuridis, Volume 4, Number 1.

Mardian Wibowo, (Juni, 2015), Menakar Konstitusionalitas Sebuah Kebijakan Hukum Terbuka Dalam Pengujian Undang-Undang, Jurnal Konstitusi, Volume 12, Number 2.

Muhamad Sofi Mubarok, (Desember, 2020), Membedah Anatomi Fiqh Siyasah Dalam Decision Mahkamah Konstitusi Tentang Presidential Threshold, Tafaqquh: Jurnal Penelitian Dan Kajian Keislaman, Volume 8, Number 2.

Muhammad Lutfi Hakim, (Juni, 2020), Hermeneutik-Negosiasi Dalam Studi Fatwa-Fatwa Keagamaan: Analisis Kritik Terhadap Pemikiran Khaled M. Abou El Fadl, Istinbath, Volume 19, Number 1.

NH Siahaan, (November, 2016), Formula Penyederhanaan Jumlah Partai Politik Di Parlemen Pada Pemilihan Umum Indonesia, Politika: Jurnal Ilmu Politik, Volume 7, Number 1.

Prasetio, et.al., (Desember, 2020), Problems of Democratic and Dignified Election in Indonesian Simultaneously Electoral Era, International Journal of Criminology and Sociology, Volume 9, Number (__ $)$.

Saiful Ansori Ansori, (2020), Maqashid Syariah Dan Praktik Sistem Presidential Threshold Di Indonesia:, Jurisprudensi: Jurnal Ilmu Syariah, PerundangUndangan, Dan Ekonomi Islam, Volume 12, Number 1.

Sholahuddin Al-Fatih, (April, 2019), Akibat Hukum Regulasi Tentang Threshold DalamPemilihan Umum Legislatif Dan Pemilihan Presiden: Kajian Decision Mahkamah Konstitusi Number 52/PUU-X/2012 Dan Number 14/PUUXI/2013, Jurnal Yudisial, Volume 12, Number 1.
Sholahuddin Al-fatih, (Oktober 2020), Electoral Regulation in Indonesia: Is It Modern Law?, Unnes Law Journal, Volume 6, Number 2.

Sholahuddin Al-Fatih, (September, 2017), Model Pengujian Peraturan PerundangUndangan Satu Atap Melalui Mahkamah Konstitusi, Jurnal Ilmiah Hukum Legality, Volume 25, Number 2.

Yogo Pamungkas, (April, 2014), Tinjauan Ambang Batas Perolehan Suara Berdasarkan UU No.8 Tahun 2012 Tentang Pemilihan Anggota DPR, DPD Dan DPRD Terhadap UUD 1945, RechtsVinding, Volume 3, Number 8.

Zennis Helen, (Oktober, 2020), Problematika Pembentukan Regulasi Pemilu Dalam Mewujudkan Pemilu Serentak Yang Demokratis, Ensiklopedia Sosial Review, Volume 2, Number 3.

\section{Paper, Essay, Thesis}

Bagian Analisis Teknis Pengawasan dan Potensi Pelanggaran, (2015), Kajian Sistem Kepartaian, Sistem Pemilu Dan Sistem Presidensiil, Sekretariat Jenderal Bawaslu RI, Jakarta: Sekretariat Jenderal Bawaslu RI

Sholahuddin Al-Fatih, (2016), Eksistensi Threshold Dalam Pemilu Serentak, Thesis, Surabaya: Magister Hukum Pemerintahan.

Vanu Fendabi, (2019), Penerapan Ambang Batas Presidensil (Presidential Threshold) Sebagai Kebijakan Hukum Terbuka Dalam Pemilihan Umum Di Indonesia (Analisis Decision Mahkamah Konstitusi Number.53/Puuxv/ 2017), Skripsi, Jakarta: Ilmu Hukum UIN Syarif Hidayatullah Jakarta.

Z. Firma Aditya and Sholahuddin Al-Fatih, (Februari, 2017), Democracy and Human Rights As A Solution To Resolve The Humanitarian Crisis In Muslim Countries, in Conference On Islamic Studies (ICIS), Yogyakarta. 


\section{Internet}

Andi Saputra, (5 Oktober 2020), MK Bawa Nasib Gugatan Rizal Ramli Soal Presidential Threshold Ke RPH, diakses pada 23 Desember 2021, detikNews, (__ $)$.

Muzakir, (2016), Pileg \& Pilpres Serentak 2019, Presidential Threshold Tidak Perlu Lagi, diakses pada 22 Desember 2021,

Poskota, http://poskotanews.com/.

Yusril Ihza Mahendra, (2015), Pemilu Serentak, Parliamentary Threshold \& Presidential Threshold Tak Ada Lagi, diakses pada 24 Desember 2021, Poskota,

http://poskotanews.com/2015/06/30/pe milu-serentak-parliamentary-tresholddan-presidential-treshold-tak-ada-lagi/

\section{Book}

Abdul Wahab Habibullah, (2015), Pemberlakuan Presidentil Threshold Dalam Pemilu Serentak, Surabaya: Airlangga.

Ahmad Al-Raysuni and Muhammad Jamal Barut, (2000), Al-Ijtihad: Al-Nass, AlWaqi', AlMaslahah, Beirut: Dar al-Fikr al-Mu'asir.

Irwansyah, (2020), Penelitian Hukum: Pilihan Metode \& Praktik Penulisan Artikel, ed. Ahsan Yunus, Yogyakarta: Mirra Buana Media.

Peter Mahmud Marzuki, (2104), Penelitian Hukum, Jakarta: Kencana Prenada Media Group.

Soetandyo Wignjosoebroto, (2002), Hukum: Paradigma, Metode Dan Dinamika Masa Lalunya, Jakarta: Huma \& Elsam. 